\title{
Lamotrigine Increases Gene Expression of GABA-A Receptor $\beta 3$ Subunit in Primary Cultured Rat Hippocampus Cells
}

Jun-Feng Wang, M.B., Ph.D., Xiujun Sun, M.B., Biao Chen, Ph.D., and L. Trevor Young, M.D., Ph.D.

To study the mechanism of action of the novel anticonvulsant and mood stabilizer lamotrigine, we used cDNA array to generate an expression profile of lamotrigine-regulated genes in primary cultured rat hippocampus cells. Gene expression was analyzed using Atlas Rat 1.2 Arrays of approximately 1200 genes. Total RNA was isolated from control and cells treated with lamotrigine at $0.1 \mathrm{mM}$ for one week and reverse-transcribed to $c D N A$ labeled with ${ }^{32} P-d A T P$. The $c D N A$ probes were hybridized with two identical cDNA array membranes. After comparing hybridized signals between these two membranes, we found that chronic treatment with lamotrigine increased the expression of eight genes and decreased the expression of six genes. One of the upregulated genes is GABA-A receptor $\beta$ subunit. This increase in GABA-A receptor $\beta 3$ subunit expression was further confirmed by Northern blotting analysis. In situ hybridization revealed that chronic treatment with lamotrigine increased $G A B A-A$ receptor $\beta 3$ subunit gene expression in $C A 1, C A 3$ and dentate gyrus of rat hippocampus. Our findings indicate that lamotrigine may effect $G A B A-A$ receptor regulated functions in the central nervous system.

[Neuropsychopharmacology 26:415-421, 2002] (C) 2002 American College of Neuropsychopharmacology. Published by Elsevier Science Inc.
KEY WORDS: Lamotrigine; cDNA array; GABA-A Receptor B3 Subunit; Gene expression; Primary cultured rat hippocampus cells; Bipolar disorder

Lamotrigine (LTG; 3,5-diamino-6-(2,3-dichlorophenyl)$1,2,4$-triazine) is a new anticonvulsant drug which clinical studies have shown to be effective in treatment of partial and secondarily generalized seizures (Binnie et al. 1989; Matsuo et al. 1993; Miller et al. 1986). In early

From the Department of Psychiatry and Behavioural Neurosciences, McMaster University, Hamilton, Ontario, Canada, L8N 3Z5

Address correspondence to: Jun-Feng Wang, HSC-4N77A, 1200 Main St. West, Hamilton, Ontario, Canada, L8N 3Z5, Tel.: (905) 5259140 ext. 22029, Fax: (905) 522-8804, E-mail: wangjf@mcmaster.ca

Received April 12, 2001; revised August 9, 2001; accepted August 21, 2001.

Online publication: 8/30/01 at www.acnp.org/citations/ Npp 083001171 clinical trials for the treatment of epilepsy, LTG was found to improve mood and more recent reports indicate that it may be effective in management of bipolar disorder. This drug has a unique profile in patients with bipolar disorder with both antidepressant and anti-cycling properties (Berk 1999; Calabrese et al. 1998; Engle and Heck 2000). Given the fact that this agent is widely prescribed in patients with bipolar disorder, understanding its mechanism of action through the identification of novel targets for the drug is clearly merited.

Pharmacological studies of LTG suggest that the drug blocks voltage-sensitive sodium channels and stabilizes neuronal membranes. For example, it has been reported that LTG reduced high frequency sustained firing of sodium-dependent action potentials in cultured mouse spinal cord neurons and voltage-sensitive sodium currents in cultured rat cerebral neurons (Che- 
ung et al. 1992; Lees and Leach 1993). LTG has also been reported to inhibit the binding of $\left[{ }^{3} \mathrm{H}\right]$ batrachotoxin $\mathrm{A}$ 20 - $\alpha$-benzoate to sodium channels (Leach et al. 1991). Although recent evidence suggest that voltage sensitive sodium channels are an important site of action for LTG, the available evidence is far from explaining the mechanism of therapeutic effect of this drug on epilepsy and bipolar disorder. Therefore, identification of specific targets for LTG with novel techniques is important, particularly if products of these targets are found to be relevant to the pathophysiology of bipolar disorder.

Recent genome projects have generated a large amount of sequence data for thousands of genes (Broder and Venter 2000; Vukmirovic and Tilghman 2000). Taking advantage of this, an important step to understanding the role of these genes in pathophysiological development of disease and drug action is to define gene expression profiles in diseased subjects or after drug manipulation. DNA expression array technology allows us to monitor the expression of hundreds of genes simultaneously and provides a format for identifying genes (Lockhart and Winzeler 2000; Rockett and Dix 2000). We used this method to isolate differentially expressed genes in rat hippocampus after administering LTG for one week and found that LTG increased the expression of a number of genes including GABA-A receptor $\beta 3$ subunit.

\section{METHODS}

\section{Primary Hippocampus Cells Culture}

Primary neuronal cell culture was performed as previously described (Brewer et al. 1993). Briefly, SpragueDawley rats of 16-18 day gestation were used for the isolation of hippocampus cells. The hippocampi were removed and submersed in ice-cold $\mathrm{Ca}^{2+}$ - and $\mathrm{Mg}^{2+}$ free Hank's balanced saline solution (Gibco, Maryland). After the meninges and blood vessels were removed, the hippocampi were washed twice with Hank's medium. Subsequently, the tissue was triturated by gently pipetting and filtered through a strainer (Becton-Dickinson Labware, New Jersey) to exclude any small tissue fragments. The filtrate containing dissociated cells was collected in a centrifuge tube and centrifuged at $300 \times \mathrm{g}$ for $5 \mathrm{~min}$. The supernatant was discarded, and the sediment was washed twice with Hank's medium and centrifuged again under the same conditions. The cell sediment was resuspended with neurobasal medium with B27 supplements (Gibco, Maryland), adjusted to approximately $10^{6} \mathrm{cell} / \mathrm{ml}$, plated into polylysine-coated plastic culture flasks and cultured at $37^{\circ} \mathrm{C}$ under $5 \%$ $\mathrm{CO}_{2}$. The cells cultured for seven days before drug treatment. Lamotrigine was obtained as a gift from Glaxo Wellcome (Mississauga, Ont) and cells cultured at various concentrations as described in the results.

\section{RNA Isolation and cDNA Array Hybridization}

Total RNA from hippocampus cells was isolated using Trizol reagent (Gibco, Maryland) following the manufacturer's instruction. The concentration of RNA was determined by measuring the OD at $260 \mathrm{~nm}$ and the purity determined by the $260 / 280$ ratio. Three $\mu \mathrm{g}$ of total RNA was subjected to electrophoresis on a denaturing $1 \%$ agarose gel to check the integrity of the RNA (18S and $28 \mathrm{~S}$ rRNA bands). After confirmation of the integrity of total RNA, mRNA was isolated using the Oligotex mRNA mini kit (Qiagen, California) according to the manufacturer's protocol.

Gene expression was analyzed using Atlas Rat 1.2 Arrays (Clontech, California) including approximately 1200 genes. Control and LTG-treated cDNA probes were generated by RNA reverse transcription under moloney murine leukemia virus (MMLV) reverse transcriptase with specific cDNA synthesis primer mix, and labeled with $\left[\alpha{ }^{32} \mathrm{P}\right] \mathrm{dATP} .{ }^{32} \mathrm{P}-$-labeled cDNA was purified from unincorporated ${ }^{32} \mathrm{P}$-labeled nucleotides and small cDNA fragments in a Chroma Spin-200 column. Four cDNA array membranes (duplicate: two for control; two for LTG treated samples) were pre-hybridized at $68^{\circ} \mathrm{C}$ for $30 \mathrm{~min}$ in ExpressHyb solution with salmon sperm DNA (100 $\mu \mathrm{g} /$ $\mathrm{ml}$ ) and hybridized at $68^{\circ} \mathrm{C}$ overnight in the same solution with equal amounts of cDNA probes of control and LTGtreated cell respectively. Membranes were washed at $68^{\circ} \mathrm{C}$ for $30 \mathrm{~min}$ in $2 \times \mathrm{SSC}, 1 \%$ SDS twice and at $68^{\circ} \mathrm{C}$ for 30 $\mathrm{min}$ in $0.1 \times \mathrm{SSC}, 0.5 \%$ SDS twice. Membranes were exposed overnight to a Phosphor Screen and scanned using a PhosphorImage (Molecular Dynamics, Inc., California).

\section{Northern Blotting Hybridization}

Total RNA from primary cultured hippocampus cells was applied to nylon membranes by capillary transfer after electrophoresis in 1\% agarose/formaldehyde gel, and ultraviolet-cross-linked. Membranes were then pre-hybridized at $42^{\circ} \mathrm{C}$ for $3 \mathrm{~h}$ in $5 \times \mathrm{SSPE}, 50 \%$ formamide, $5 \times$ Denhardt's, $1.0 \%$ SDS, $5 \%$ dextran sulfate, salmon sperm DNA $(100 \mu \mathrm{g} / \mathrm{ml})$ and hybridized at $42^{\circ} \mathrm{C}$ overnight in this buffer with GABA-A receptor $\beta 3$ subunit cDNA probes generated by RT-PCR. CDNA probes were labeled with $\left[\alpha{ }^{-32} \mathrm{P}\right] \mathrm{dCTP}$ by using a random prime labeling method (Feinberg and Vogelstein 1983). Membranes were then washed at room temperature for 45 $\min$ in $2 \times$ SSPE, $0.1 \%$ SDS twice and at $58^{\circ} \mathrm{C}$ for $15 \mathrm{~min}$ in $0.1 \times$ SSPE, $0.1 \%$ SDS twice. Membranes were exposed overnight to a Phosphor Screen and scanned using a PhosphorImage (Molecular Dynamics, Inc., California).

\section{In Situ Hybridization}

Male Sprague-Dawley rats (180-200 g) were divided into two groups: control $(n=5)$ and LTG treated group 
$(n=5)$. Each group of rats was injected intraperitoneally with vehicle and LTG $(30 \mathrm{mg} / \mathrm{kg}$ ) respectively daily for two weeks. After drug treatment, rats were anesthetized with sodium pentobarbital $(60 \mathrm{mg} / \mathrm{kg})$ and perfused transcardially with $250 \mathrm{ml}$ of $100 \mathrm{mM}$ phosphate buffer $(\mathrm{pH} 7.5)$ at room temperature. Brains were removed, rapidly frozen in $-80^{\circ} \mathrm{C}$ and serial $10 \mu \mathrm{m}$ coronal sections (from Bregma $-2.30 \mathrm{~mm}$ to Bregma $-4.80 \mathrm{~mm}$ ) prepared at $-18^{\circ} \mathrm{C}$. The sections were thaw-mounted on poly-L-lysine coated glass slides.

Slices were washed twice in each of the following conditions: in PBS for $5 \mathrm{~min}$, in PBS containing $100 \mathrm{mM}$ glycine for $5 \mathrm{~min}$, in PBS containing 0.3\% Triton X-100 for $15 \mathrm{~min}$, and in PBS for $5 \mathrm{~min}$. Then slices were incubated in TE buffer ( $\mathrm{pH}$ 8.0) containing $1 \mu \mathrm{g} / \mathrm{ml}$ RNasefree Proteinase K (Sigma, Canada) for $30 \mathrm{~min}$ at $37^{\circ} \mathrm{C}$ and fixed in $4 \%$ paraformaldehyde. The slices were further incubated in $0.1 \mathrm{M}$ triethanolamine buffer $(\mathrm{pH} 8.0)$ with $0.25 \%(\mathrm{v} / \mathrm{v})$ acetic anhydride for $15 \mathrm{~min}$ and prehybridized in $47 \%$ formamide, $2 \times$ SSC, $1 \times$ Denhardt, $500 \mu \mathrm{g} / \mathrm{ml}$ salmon sperm DNA, $50 \mathrm{mM}$ DTT, $250 \mu \mathrm{g} / \mathrm{ml}$ yeast t-RNA, $5 \mu \mathrm{g} / \mathrm{ml}$ poly(dA), $100 \mu \mathrm{g} / \mathrm{ml}$ poly(A), for $2 \mathrm{~h}$ at $37^{\circ} \mathrm{C}$, and hybridized at $37^{\circ} \mathrm{C}$ overnight using oligo probes labeled with DIG (Roche, Canada). The slices were then washed at $37^{\circ} \mathrm{C}$ in $2 \times$ SSC, $0.05 \%$ SDS for $15 \mathrm{~min}$, in $2 \times$ SSC twice for $15 \mathrm{~min}, 1 \times$ SSC twice for $15 \mathrm{~min}$ and $0.25 \times$ SSC twice for $15 \mathrm{~min}$. Immunological detection was performed with DIG Nucleic Acid Detection Kit (Roche, Canada) according to the manufacturer's protocol.

\section{Analysis and Interpretation of Data}

Differential expression in cDNA arrays after LTG treatment was identified using AtlasImage Software from Clontech (California). Data from Northern blotting analysis were obtained by densitometric analysis of autoradiograms using ImageQuant from Molecular Dynamics (California). Results were expressed as percent of control. Changes in gene expression after drug treatment were expressed as the mean \pm SEM from three separate experiments. Statistical significance of differences between means was determined by Student's $t$ tests or one way ANOVA.

\section{RESULTS}

Primary cultured hippocampal cells were chronically treated with vehicle (control) or $0.1 \mathrm{mM}$ LTG for one week. DNA array hybridization was used to identify differentially expressed genes between control and LTG treated cells using Atlas cDNA Express Array membranes containing approximately 1200 genes, including transcription factors, ion channels, transport proteins, and receptors, among others. cDNA probes generated from control or LTG treated cells were used to hybridize with two identical cDNA array membranes respectively. By comparing hybridized blots for control versus LTG treated cells, we identified a number of LTG regulated genes. The hybridization results are summarized in Table 1. Only genes with expression levels that were altered by at least 1.25 -fold between control and LTG treated cells are included. We found chronic treatment with LTG for one week increased expression of eight genes and decreased expression of six genes. Four representative differentially expressed genes (GABA-A receptor $\beta 3$ subunit, somatostatin, protein tau, and neural visinin-like $\mathrm{Ca}^{2+}$-binding protein) are marked in Figure 1.

Because GABA-A receptor $\beta 3$ subunit gene expression showed the greatest increase by LTG among these fourteen differentially expressed genes, and because GABA-A receptor is a common target of a number of anticonvulsants, GABA-A receptor was chosen for further studies of the effect of LTG. First, partial cDNA sequence of GABA-A receptor $\beta 3$ subunit was used as a probe to hybridize with Northern blots containing total RNA from control and LTG treated cells to confirm their differential expression. These partial cDNA sequence probes were generated by RT-PCR and radioactively labeled. The expression of GABA-A receptor $\beta 3$ subunit mRNA was increased by $84 \pm 36 \%(p<.05, n=$ 6) after chronic treatment with $0.1 \mathrm{mM}$ LTG for one week (Figure 2). Second, we studied the dose response

Table 1. Summary of Differentially Expressed Genes between Control (CTL) and Lamotrigine (LTG) Treated Primary Cultured Rat Hippocampal Cell

\begin{tabular}{|c|c|c|}
\hline $\begin{array}{l}\text { GenBank } \\
\text { No. }\end{array}$ & $\begin{array}{l}\text { Ratio } \\
\text { (LTG/CTL) }\end{array}$ & Gene Name \\
\hline X15468 & 1.78 & GABA-A receptor $\beta 3$ subunit \\
\hline X07286 & 1.68 & Protein kinase $C \alpha$ type \\
\hline D38629 & 1.64 & $\begin{array}{l}\text { Adenomatous polyposis } \\
\text { coli protein }\end{array}$ \\
\hline D10666 & 1.63 & $\begin{array}{l}\text { Neural visinin-like } \mathrm{Ca}^{2+} \\
\text { binding protein }\end{array}$ \\
\hline M25890 & 1.56 & Somatostatin \\
\hline Х61159 & 1.46 & Glycine receptor $\alpha 2 \mathrm{~A}$ subunit \\
\hline U41744 & 1.41 & PDGF-associated protein \\
\hline M31809 & 1.31 & $\begin{array}{l}\text { Serine/threonine protein } \\
\text { phosphatase } 2 \text { B catalytic } \\
\text { subunit } \beta\end{array}$ \\
\hline M34728 & 0.79 & $\begin{array}{l}\text { Nonspecific lipid-transfer } \\
\text { protein precursor }\end{array}$ \\
\hline D17614 & 0.74 & $14-3-3$ protein tau \\
\hline X56917 & 0.65 & $\begin{array}{l}\text { 1D-myo-inositol-trisphosphate } \\
\text { 3-kinase A }\end{array}$ \\
\hline D42145 & 0.66 & $\begin{array}{l}\text { ATP-sensitive inward rectifier } \\
\text { potassium subfamily } \mathrm{J} \\
\text { membrane } 8\end{array}$ \\
\hline M22642 & 0.55 & Cytosolic thymidine kinase \\
\hline U16253 & 0.52 & $\begin{array}{l}\text { Corticotropin-releasing factor } \\
\text { receptor subtype } 2\end{array}$ \\
\hline
\end{tabular}




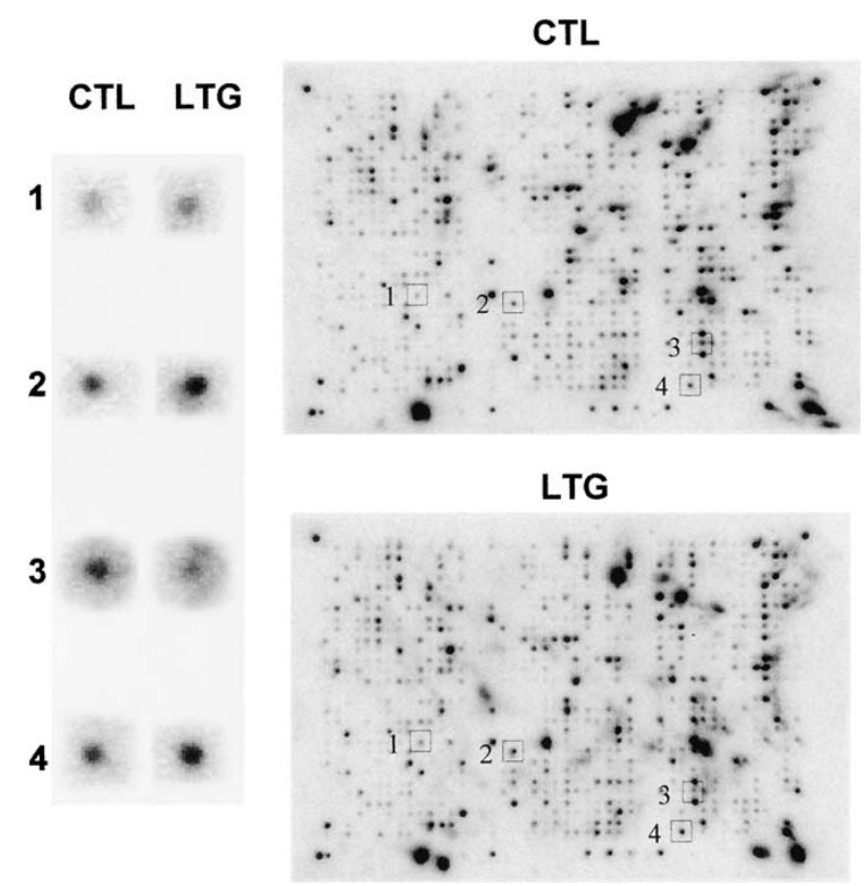

Figure 1. Differential expression of genes between control (CTL) and lamotrigine (LTG) treated primary cultured rat hippocampal cells. Four representative differentially expressed genes are marked in $\square$. GABA-A receptor $\beta 3$ subunit (1), somatostatin (2), and neural visinin-like $\mathrm{Ca}^{2+}$-binding protein (4) are increased by LTG and protein tau (3) is decreased by LTG.

effect of LTG on GABA-A receptor $\beta 3$ subunit expression. Chronic treatment with LTG increased mRNA level of GABA-A receptor $\beta 3$ subunit in a dose-dependent manner. LTG at concentration of $0.03,0.1$ and 0.3 $\mathrm{mM}$ increased mRNA expression of GABA-A receptor $\beta$ subunit by $66 \pm 31 \%(p>.05, n=3), 99 \pm 28 \%(p<$ $.05, n=3)$ and $155 \pm 56 \%(p<.01, n=3)$ (Figure 3). Third, we studied the brain regional expression of GABAA receptor $\beta 3$ subunit after chronic treatment with LTG. In situ hybridization analysis showed that chronic treatment with LTG increased GABA-A receptor $\beta 3$ subunit gene expression to the greatest degree in CA1 and dentate gyrus regions of hippocampus, moderately in frontal cortex, parietal cortex and CA3, and not at all in thalamus (Figure 4).

\section{DISCUSSION}

In the present study, we profiled differentially expressed genes in rat primary hippocampus cells after chronic treatment with LTG using cDNA array technology. From our results, it is clear that chronic treatment with LTG for one week regulates expression of a number of genes, most of which have not been previously documented in pharmalogical action of either anticonvulsants or mood stabilizers. Further characterization of these

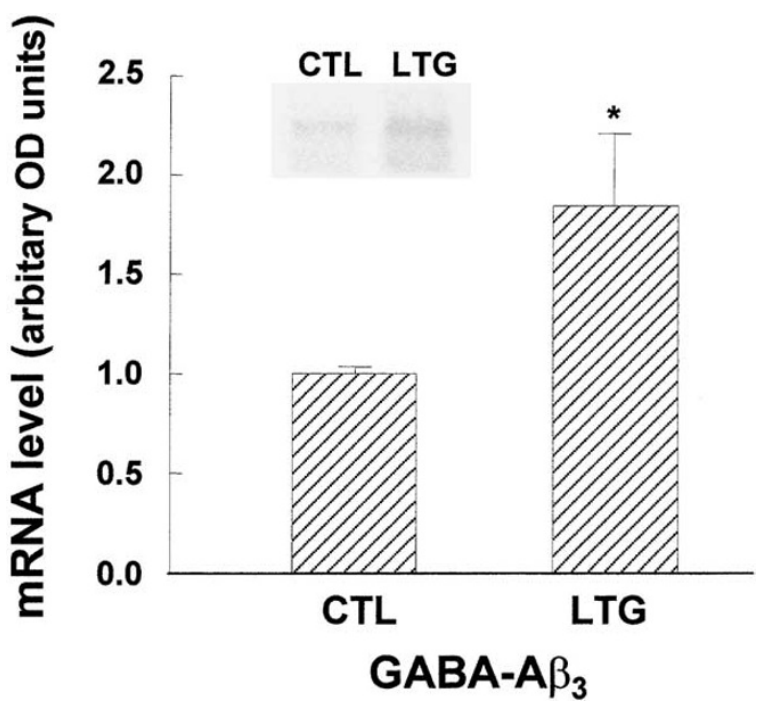

Figure 2. Northern blot analysis of GABA-A receptor $\beta 3$ (GABA-A 33 ) subunit. Total RNA was isolated from primary cultured rat hippocampal cell grown without (CTL) or with $0.1 \mathrm{mM}$ lamotrigine (LTG) for 1 week. RNA (15 $\mu \mathrm{g})$ was analyzed by Northern blot analysis using ${ }^{32} \mathrm{P}-\mathrm{dCTP}$ labeled probe of GABA-A 33 . Autoradiograms were quantitated by densitometry. Results are the mean \pm SEM. * indicates $p<$ .05 when compared with control cells.

genes regulated by LTG may help us to gain new insights into the action of this drug. Among these genes, it is of interest to note that expression of inhibitory neurotransmitter GABA-A receptor $\beta 3$ subunit is regulated by chronic treatment with LTG, since regulation of GABA is shared by various anticonvulsants. For example, it has been found that the benzodiazepines diazepam and flunitrazepam increased the opening frequency and conductance of GABA-A receptor channels in primary cultured rat cortical and hippocampal neurons (Eghbali et al. 1997; Vicini et al. 1987). Barbiturates have also been shown to increase the GABA receptor channel mean open time in mouse spinal neurons (MacDonald et al. 1989; Twyman et al. 1989). Using Northern blotting analysis and in situ hybridization, we further verified that LTG increases the expression of GABA-A receptor $\beta 3$ subunit in rat hippocampus. Our findings suggest that regulation of GABA-A receptor may also be a target of LTG.

In the central nervous system, GABA binds specific sites of GABA-A receptors and then opens the intrinsic chloride channel, which leads to chloride influx. Activation of GABA-A receptors causes a hyperpolarization of cell membrane and inhibits the electrical activity of neurons (Bormann 2000; Chebib and Johnston 1999; Olsen et al. 1999). GABA-A receptors have been reported to be an important site of action of anticonvulsants (Pesold et al. 1997; Teuber et al. 1999; Tietz et al. 1999). The $\beta 3$ subunit of GABA-A receptor is highly ex- 


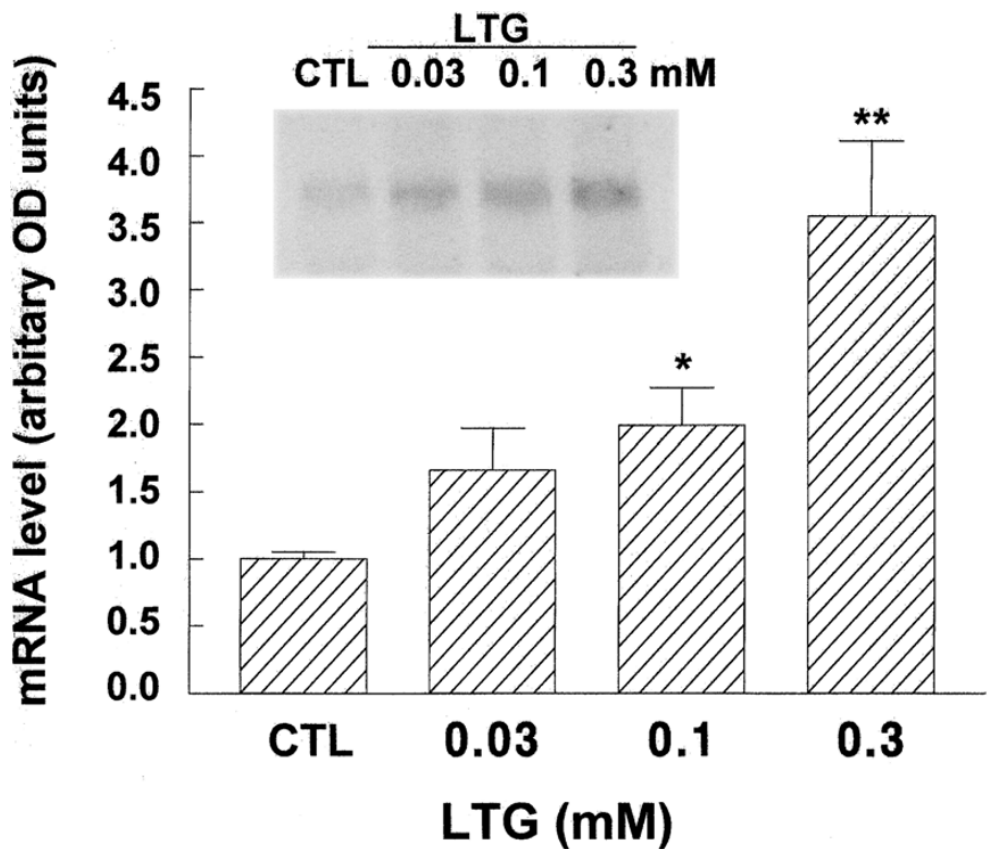

Figure 3. Effect of lamotrigine (LTG) on the expression of GABA-A receptor $\beta 3$ subunit (GABA-A $\beta$ ) mRNA levels. Primary cultured rat hippocampus cells were grown for 1 week under $0.03-0.3 \mathrm{mM}$ LTG. Control cells (CTL) were treated identically but without addition of drugs. Total RNA (15 $\mu \mathrm{g})$ was analyzed by Northern blotting hybridization using ${ }^{32} \mathrm{P}-\mathrm{dCTP}$ labeled probe of GABA-A 33 . Autoradiograms were quantitated by densitometry. Results are the mean \pm SEM. * indicates $p<$ .05 and ${ }^{* *}$ indicates $p<.01$ when compared with control cells.

pressed in the brain, and it is a component of a high proportion of GABA-A receptors. $\beta 3$ subunit of GABA receptor complex is a component of critical importance for GABA binding (Li and De Blas 1997; Miralles et al. 1999). Site-directed mutagenesis studies have identified domains of the $\beta 3$ subunit which are important for activa- tion by GABA (Amin and Weiss 1993). $\beta 3$ subunit mutant mice show epilepsy and neurological disorder (DeLorey et al. 1998; Homanics et al. 1997). An increase of $\beta 3$ subunit expression by LTG in hippocampus suggests that LTG, like other anticonvulsants may also produce inhibitory effect in the brain by regulating GABA-A receptor.
CTL
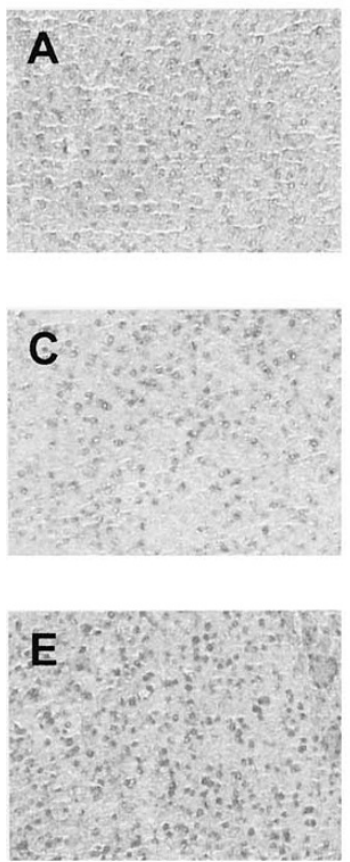

LTG
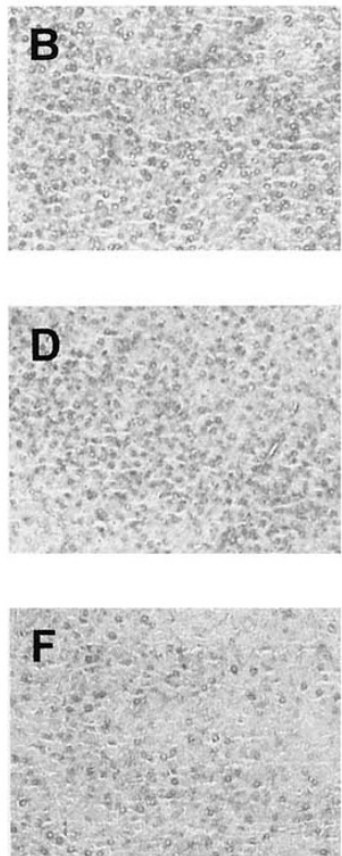

CTL
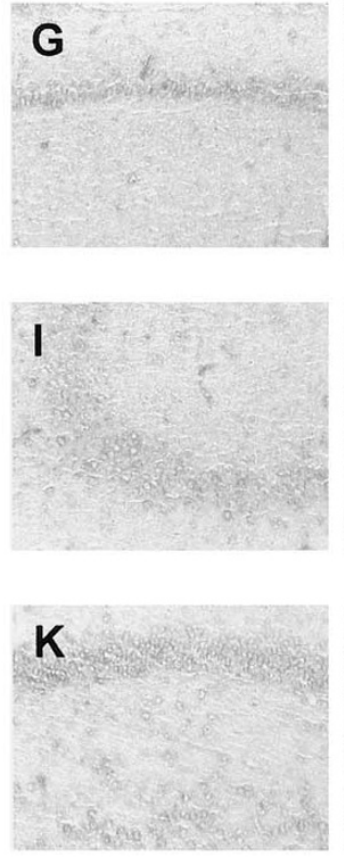

LTG
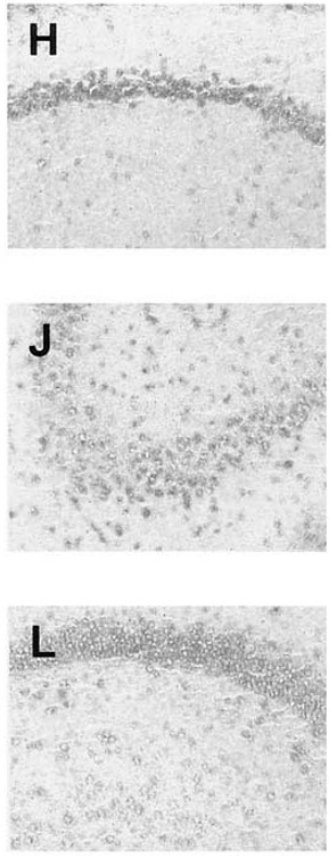

Figure 4. Effect of lamotrigine (LTG) on gene expression of GABA-A receptor $\beta 3$ (GABA-A 33 ) subunit in frontal cortex (A and $\mathrm{B}$ ), parietal cortex (C and D), thalamus (E and F), CA1 (G and H), CA3 (I and J) and dentate gyrus (K and L) regions of rat brain. Tissue sections were hybridized with a DIG-labeled GABA-A 33 cDNA oligo. 
Previous electrophysiological and neurochemical studies suggest that LTG may have a direct interaction with voltage-activated sodium channel and may act by inhibiting voltage sensitive sodium channels, limiting neuronal excitability, stabilizing neuronal membrane and blocking excitatory amino acid release (Cheung et al. 1992; Leach et al. 1986 and 1991; Lees and Leach 1993). For example LTG was found to reduce sustained repetitive firing of sodium-dependent action potentials in mouse spinal cord cultured neurons and $\left[{ }^{3} \mathrm{H}\right]$ batrachotoxin A $20-\alpha$-benzoate binding to the voltage-sensitive sodium channel in rat brain synaptosomes (Cheung et al. 1992; Leach et al. 1991). LTG also selectively blocked sodium channel activator veratrine induced release of endogenous glutamate from slices of rat cerebral cortex, suggesting that the reduction in glutamate release may be due to blockade of sodium channel (Leach et al. 1986). In the present study, we found that LTG upregulated GABA-A receptors. Our results suggest that LTG may augment GABAergic inhibition. It is known that activation of GABA-A results in opening of $\mathrm{Cl}^{-}$channel and increases the influx of $\mathrm{Cl}^{-}$. An increase in $\mathrm{Cl}^{-}$conductance can reduce depolarization, decrease the $\mathrm{Ca}^{2+}$ influx during action potential and further inhibit excitatory amino acid release (Whiting et al. 1999). Indeed, it was reported that LTG at therapeutic doses inhibited voltage activated $\mathrm{Ca}^{2+}$ currents in rat cortical neuron (Stefani et al. 1996). Together these findings suggest that the inhibitory effect of LTG on release of excitatory amino acid glutamate may be produced by either inhibition of sodium channels or possibly increased expression of inhibitory amino acid GABA and related functional activity. This finding also implies that the mechanism of action of LTG in epilepsy and bipolar disorder may involve a decrease in intrinsic neuronal excitability through direct blockade of sodium channels and augmention of GABAergic inhibition. In this regard, another laboratory found that the anticonvulsant, 3-Benzyl-3-ethyl-2-piperidinone (3-BEP), also regulated the GABA-A receptor and sodium channel (Hill et al. 1998). Indeed 3-BEP not only modulates GABA-A receptor in a manner similar to the benzodiazepines, but also inhibits voltage-dependent sodium current. Further studies should examine the functional regulation of GABA-A receptor by LTG to further understand the potential significance of this finding in the pharmacological mechanism of LTG. Studies with other mood stabilizing anticonvulsants, which are the mainstay of treatment for this illness, will help to clarify whether this target is shared by other drugs in this class.

\section{ACKNOWLEDGMENTS}

This work is supported by grants from Canadian Institute of Health Research (LTY and JFW) and the Stanley Foundation
(LTY). LTY is a Career Scientist of the Ontario Ministry of Health. BC is a research fellow of Canadian Psychiatric Research Foundation.

\section{REFERENCES}

Amin J, Weiss DS (1993): GABAA receptor needs two homologous domains of the beta-subunit for activation by GABA but not by pentobarbital. [see comments] Nature 366:565-9

Berk M (1999): Lamotrigine and the treatment of mania in bipolar disorder. Eur Neuropsychopharmacol 9(Suppl 4):S119-S123

Binnie CD, Debets RM, Engelsman M, Meijer JW, Meinardi $\mathrm{H}$, Overweg J, Peck AW, Van Wieringen A, Yuen WC (1989): Double-blind crossover trial of lamotrigine (Lamictal) as add-on therapy in intractable epilepsy. Epilepsy Res 4:222-229

Bormann I (2000): The 'ABC' of GABA receptors. Trends Pharmacol Sci 21:16-19

Brewer GJ, Torricelli JR, Evege EK, Price PJ (1993): Optimized survival of hippocampal neurons in B27-supplemented Neurobasal, a new serum-free medium combination. J Neurosci Res 35:567-576

Broder S, Venter JC (2000): Sequencing the entire genomes of free-living organisms: the foundation of pharmacology in the new millennium. Annu Rev Pharmacol Toxicol 40:97-132

Calabrese JR, Rapport DJ, Shelton MD, Kujawa M, Kimmel SE (1998): Clinical studies on the use of lamotrigine in bipolar disorder. Neuropsychobiology 38:185-191

Chebib M, Johnston GA (1999): The 'ABC' of GABA receptors: a brief review. Clin Exp Pharmacol Physiol 26:937-940

Cheung H, Kamp D, Harris E (1992): An in vitro investigation of the action of lamotrigine on neuronal voltageactivated sodium channels. Epilepsy Res 13:107-112

DeLorey TM, Handforth A, Anagnostaras SG, Homanics GE, Minassian BA, Asatourian A, Fanselow MS, DelgadoEscueta A, Ellison GD, Olsen RW (1998): Mice lacking the beta3 subunit of the GABAA receptor have the epilepsy phenotype and many of the behavioral characteristics of Angelman syndrome. J Neurosci 18: 8505-8514

Eghbali M, Curmi JP, Birnir B, Gage PW (1997): Hippocampal GABA(A) channel conductance increased by diazepam. Nature 388:71-75

Engle PM, Heck AM (2000): Lamotrigine for the treatment of bipolar disorder. Ann Pharmacother 34:258-262

Feinberg AP, Vogelstein B (1983): A technique for radiolabeling DNA restriction endonuclease fragments to high specific activity. Anal Biochem 132:6-13

Hill MW, Reddy PA, Covey DF, Rothman SM (1998): Inhibition of voltage-dependent sodium channels by the anticonvulsant gamma-aminobutyric acid type A receptor modulator, 3-benzyl-3-ethyl-2-piperidinone. J Pharmacol Exp Ther 285:1303-1309

Homanics GE, DeLorey TM, Firestone LL, Quinlan JJ, Handforth A, Harrison NL, Krasowski MD, Rick CE, Korpi ER, Mäkelä R, Brilliant MH, Hagiwara N, Ferguson C, Snyder K, Olsen RW (1997): Mice devoid of gamma- 
aminobutyrate type A receptor beta3 subunit have epilepsy, cleft palate, and hypersensitive behavior. Proc Natl Acad Sci USA 94:4143-4148

Leach MJ, Baxter MG, Critchley MA (1991): Neurochemical and behavioral aspects of lamotrigine. Epilepsia 32(Suppl 2):S4-8

Leach MJ, Marden CM, Miller AA (1986): Pharmacological studies on lamotrigine, a novel potential antiepileptic drug: II. Neurochemical studies on the mechanism of action. Epilepsia 27:490-497

Lees G, Leach MJ (1993): Studies on the mechanism of action of the novel anticonvulsant lamotrigine (Lamictal) using primary neurological cultures from rat cortex. Brain Res 612:190-199

Li M, De Blas AL (1997): Coexistence of two beta subunit isoforms in the same gamma-aminobutyric acid type A receptor. J Biol Chem 272:16564-16569

Lockhart DJ, Winzeler EA (2000): Genomics, gene expression and DNA arrays. Nature 405:827-836

MacDonald RL, Rogers CJ, Twyman RE (1989): Barbituate regulation of kinetic properties of the GABAA receptor channel of mouse spinal neurones in culture. J Physiol 417:483-500

Matsuo F, Bergen D, Faught E, Messenheimer JA, Dren AT, Rudd GD, Lineberry CG (1993): Placebo-controlled study of the efficacy and safety of lamotrigine in patients with partial seizures. U.S. Lamotrigine Protocol 0.5 Clinical Trial Group. Neurology 43:2284-2291

Miller AA, Wheatley P, Sawyer DA, Baxter MG, Roth B (1986): Pharmacological studies on lamotrigine, a novel potential antiepileptic drug: I. Anticonvulsant profile in mice and rats. Epilepsia 27:483-489

Miralles CP, Li M, Mehta AK, Khan ZU, De Blas AL (1999): Immunocytochemical localization of the beta(3) subunit of the gamma-aminobutyric acid(A) receptor in the rat brain. J Comp Neurol 413:535-548
Olsen RW, DeLorey TM, Gordey M, Kang MH (1999): GABA receptor function and epilepsy. Adv Neurol 79: 499-510

Pesold C, Caruncho HJ, Impagnatiello F, Berg MJ, Fritschy JM, Guidotti A, Costa E (1997): Tolerance to diazepam and changes in $\mathrm{GABA}(\mathrm{A})$ receptor subunit expression in rat neocortical areas. Neuroscience 79:477-487

Rockett JC, Dix DJ (2000): DNA arrays: technology, options and toxicological applications. Xenobiotica 30:155-177

Stefani A, Spadoni F, Siniscalchi A, Bernardi G (1996): Lamotrigine inhibits $\mathrm{Ca}^{2+}$ currents in cortical neurons: functional implications. Eur J Pharmacol 307:113-116

Teuber L, Wätjens F, Jensen LH (1999): Ligands for the benzodiazepine binding site-a survey. Curr Pharm Des 5: 317-343

Tietz EI, Huang X, Chen S, Ferencak WF (1999): Temporal and regional regulation of alpha1, beta2 and beta3, but not alpha2, alpha4, alpha5, alpha6, beta1 or gamma2 GABA(A) receptor subunit messenger RNAs following one-week oral flurazepam administration. Neuroscience 91:327-341

Twyman RE, Rogers CJ, Macdonald RL (1989): Differential regulation of gamma-aminobutyric acid receptor channels by diazepam and phenobarbital. Ann Neurol 25: 213-220

Vicini S, Mienville JM, Costa E (1987): Actions of benzodiazepine and beta-carboline derivatives on gamma-aminobutyric acid-activated $\mathrm{Cl}$ - channels recorded from membrane patches of neonatal rat cortical neurons in culture. J Pharmacol Exp Ther 243:1195-1201

Vukmirovic OG, Tilghman SM (2000): Exploring genome space. Nature 405:820-822

Whiting PJ, Bonnert TP, McKernan RM, Farrar S, Le Bourdellès B, Heavens RP, Smith DW, Hewson L, Rigby MR, Sirinathsinghii DJ, Thompson SA, Wafford KA (1999): Molecular and functional diversity of the expanding GABA-A receptor gene family. Ann N Y Acad Sci 868: 645-53 